\title{
(Re-)Translating Zich's Aesthetics into English: A Work in Progress
}

\author{
Tomáš Kačer, David Drozd
}

An English translation of Zich's seminal book The Aesthetics of Dramatic Art (1931) remains an unfinished task of Czech theatre studies, a debt to the discipline as such. The book is a groundwork of Czech theatre theory terminology and its introduction to international readership has been as necessary, since this is the only way its relevance could be established and proven, as it has proven challenging. Czech structuralist theatre studies often refer to Zich, especially in writings of the Prague School which have become widely read and acclaimed. For this reason, it seems all the more crucial to produce an English translation of the book, which is referenced in studies by Jan Mukařovský, Jiří Veltruský and Jindřich Honzl, to name but few internationally recognized Prague School theatre theorists.

But consider difficulties of such challenge: Zich's language is overly complicated. Although he writes in Czech, stylistically he employs a syntactic complexity typical of $19^{\text {th }}$ century German philosophy; for instance, at times he constructs overcomplicated sentences of up to 10 lines which make a coherent logical argument of their own. His terminology, as discussed below, is idiosyncratic (as any new terminology tends to be). It is often based on subtle language nuances rooted in the structure of Czech (such as souhra, where 'hra' is play or action, and the prefix 'sou-' implies a coordinated, harmonious intention of all participants: a conscious interaction), and at times it derives its terminology from German expressions. The most obvious case of the latter would be key concept of Zich's book, významová představa, which is derived from the German Bedeutungsvorstellung, a term coined by Johannes Volkelt, at that time an influential German aesthetician and psychologist. The German provides one single long word, whereas in Czech it becomes two, and in English the term provides issues for neverending discussions among theorists. Last but not least, Zich's book presents a carefully built theory (constructed from axioms to complex statements), which means that any particular terminology in translation needs to be considered from the perspective of the whole book.

Ivo Osolsobě (1928-2012) was the first to initiate an English translation. He worked as dramaturg of the Brno operetta house, but besides his 'practical' job he was one of the most active Czech theoreticians of theatre. One of his first important studies, 'Dramatic art as communication through communication about communication' (OSOLSOBĚ 1970) is - symptomatically - a treatise 'translating' Zich's definition of theatre into terminologies utilized in semiotics, cybernetics, game theory and computer science. Two aspects of this translation were ground-breaking at the time: first, 
Osolsobě was the first who took Zich seriously as a theoretician after 1945 (a fact which reveals much about theatre at that time); and second, Osolsobě proves Zich's relevance by 'rewording' his concepts into an up-to-date terminology. (Moreover, Osolsobě also provides a definition of theatre which has remained relevant and universal).

The interest of Osolsobě led to many studies on Otakar Zich, crowned by a second Czech and the first critical edition of The Aesthetics (1986), which Osolsobě provided with an extensive afterword and commentaries (with Miroslav Procházka). Osolsobě has established many links with European and American semioticians since the 1960s (Roman Jakobson had suggested him for the executive board of the International Association for Semiotics Studies (IASS-AIS) in 1971). Osolsobě took part in many semiotic conferences and contributed to numerous publications (for example, he provided entries in the Encyclopedic Dictionary of Semiotics (SEBEOK and DANESI 1986). In other words, Osolsobě was ready for such a challenge as that presented by Zich's work.

Osolsobě invited Samuel Kostomlatský (1895-1984), a retired professor of English from Brno, to cooperate on the translation. Kostomlastký provided the first translation draft (a typed manuscript), which Osolsobě then edited. We have no evidence of the two scholars actually getting together to work on the text, but we may conclude from various publications by Osolsobě (see OSOLSOBĚ 2007a [1975] and OSOLSOBĚ 2007b) that Kostomlatský had finished the first draft of his translation already around 1975 and from then on Osolsobě used every opportunity to discuss the English with anyone who was willing and available. For example, when spending a year on research in the Netherlands in 1981 he initiated a seminar to discuss the unpublished translation. We may assume from his correspondence with Jiří Veltruský, who was living in Paris at that time, that Osolsobě provided Veltruský a copy of the manuscript to peruse to the terminology. Osolsobě probably even negotiated with publishing houses - he mentions de Ridder (who rejected it). He at least attempted to bring it to the interest of Ladislav Matejka (who was executive head of Michigan Slavic Publications in the 1980s). For reasons unknown, the publication project was never finished.

The English translation manuscript is typed on A4 sheets, quite clear and readable. Osolsobě's notes, sometimes very extensive ones, appear on the first 70 pages, which contain the first three crucial, general theoretical chapters of the book. The rest bears only minor corrections, although it is difficult to speculate why Osolsobě refrained from correcting the rest of the text, as there are evident terminological inconsistencies in Kostomlatskýs draft which require an editor's hand. Still, there are no other versions of Zich's text in English with which to compare the manuscript.

Immediately below a facsimile of the typescript can be found, followed by a transcript and, finally, the Czech original is aligned with a passage from Kostomlatský and Osolsobě's English translation paired with our current English retranslation. A discussion of several issues related to the translation process follows. 


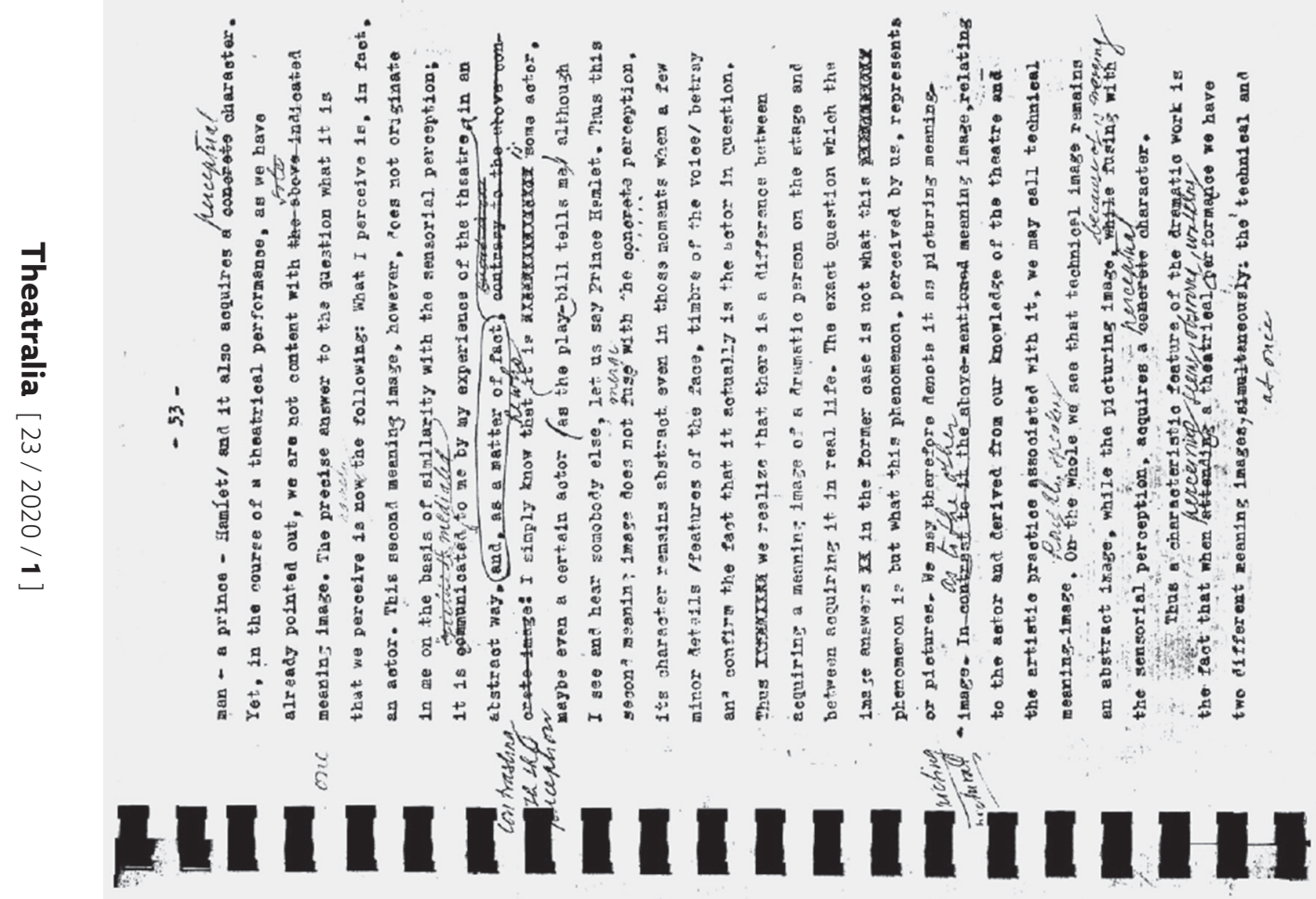

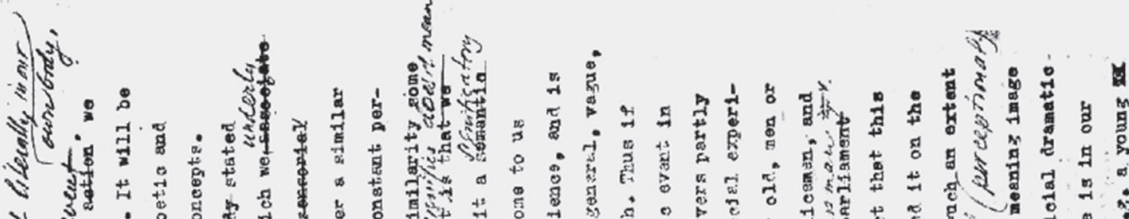
ฟै (

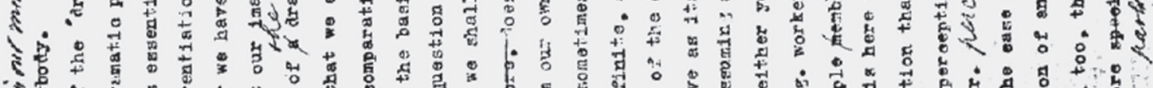

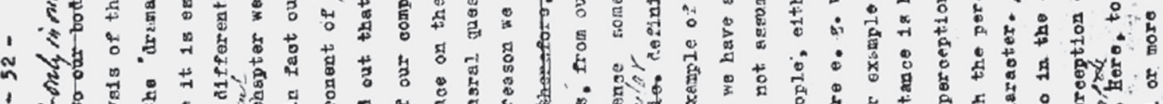

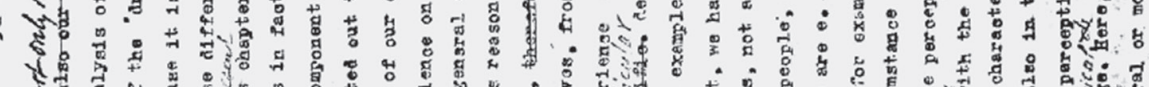
作

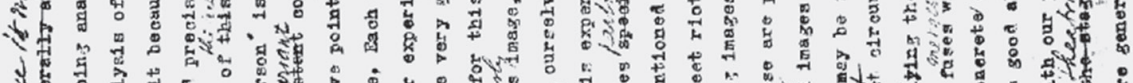

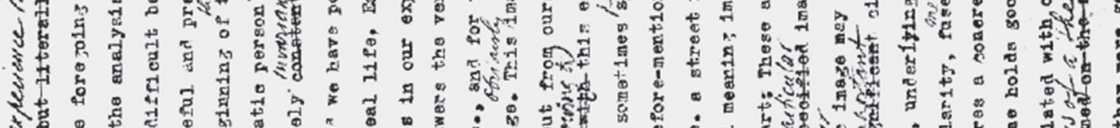

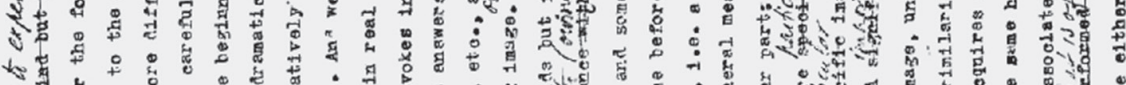
S

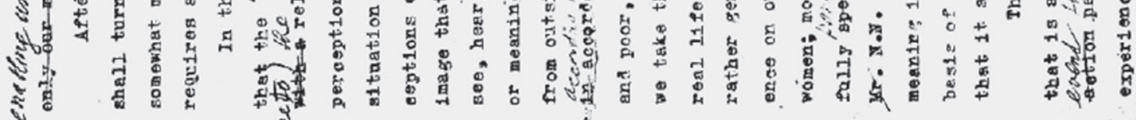



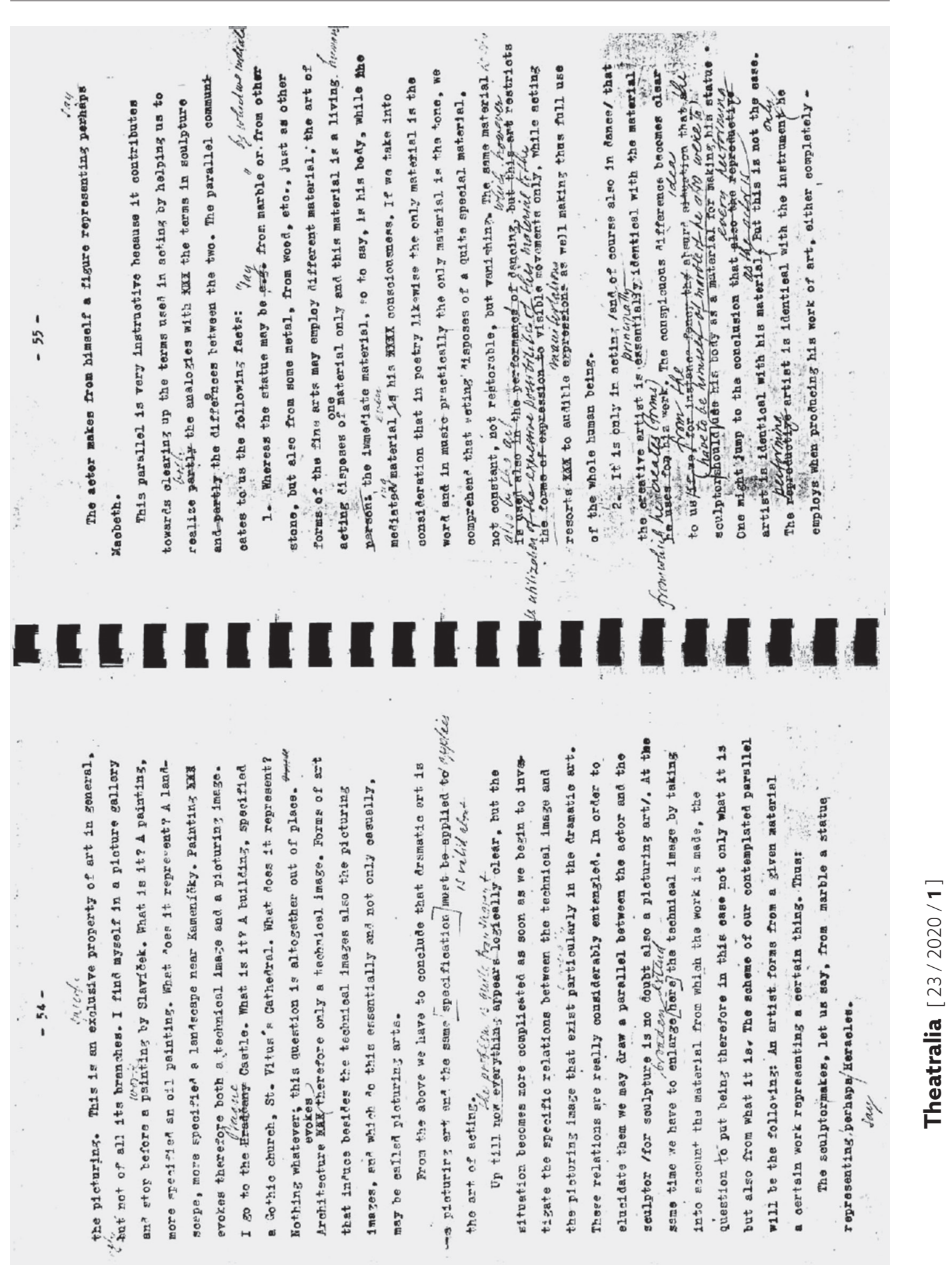
The passage we are concerned with is found on pages 52-54 of the Kostomlatský and Osolsobě typescript. It consists of five paragraphs total, separated by empty lines before and after the section, while not distinguished graphically from the remaining text in the translation. As a typescript, the translation also forgoes formatting such as italics and interlacing. The typescript is that of Kostomlatský, while the editorial handwritten pen-marks are Osolsobě's.

In the transcript below, we are including Osolsobě's edits in italics, while other editorial emendations are simulated by visually similar methods. For example, we use the strikethrough for crossed-out words in the typescript. Handwritten edits are found above the text for which they substitute in the typescript, whereas we include them after the substituted text, which is marked as a strikethrough or in brackets, depending on the handwritten marks on the typescript.

After the foregoing analysis of the 'dramatic action event' we shall turn to the analysis of the 'dramatic person'. It will be somewhat more difficult because it is essentially noetic and requires a careful and precise differentiation of concepts.

In the beginning of this the present chapter we have already stated that the 'dramatic person' is in fact our image, which we associate a [under] hypostatize to the relatively eonstant invariant component of a the dramatic serception. And we have pointed out that we encounter a similar situation in real life. Each of our comparatively constant perceptions evokes in our experience on the basis of similarity some image that answers the very general question what it is signifies does it mean that we see, hear, etc., and for this reason we shall call it a semantic significatory or meaning image. Obviously This image, therefore, does not come to us from outside but from ourselves, from our own experiences, and is

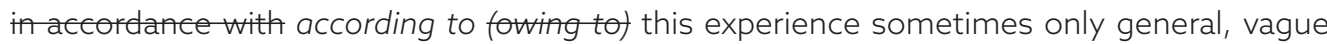
and poor, and sometimes specific particular, definite, and rich. Thus if we take the beforementioned example of the dramatic event in real life, i.e. a street riot, we have as its observers partly rather general meaning images, not assuming any special experience on our part: These are people, either young or old, men or women; more specified particular images are e.g. workers, policemen, and fully specific particular image may be for ex ample member-ofparliament Mr. congressman N.N. A significant important circumstance is here the fact that this meaning image, underlying the perception that evoked it on the basis of similarity, fuses merges with the perception to such an extent that it acquires a eorete perceptual (perceptional) character.

The same holds good also in the case of the meaning image that is associated with our perception of an artificial dramatic action performed on the stage event that is of a theatrical [sic]. Here, too, the image is in our experience either more general or more specific particular (e.g. young man - a prince - Hamlet) and it also acquires a concrete perceptual character. Yet, in the course of a theatrical performance, as we have already pointed out, we are not content with the meaning image The precise answer to the question what it is that we perceive is namely the following: What I perceive is, in fact, an actor. This second meaning image, however, does not originate in me on the basis of similarity with the sensorial perceptions; it is communicated mediated to me by my experience of the theatre, and, 
as a matter of fact, in an abstract way contrary to the above concrete image contrasting with the perception: I simply know that it is he who is some actor, maybe even a certain actor (as the play-bill tells me) although I see and hear somebody else, let us say Prince Hamlet. Thus this second meaning image does not fuse merge with the concrete perception, its character remains abstract even in those moments when a few minor details (features of the face, timbre of the voice) betray and confirm the fact that it actually is the actor in question. Thus we realize that there is a difference between acquiring a meaning image of a dramatic person on the stage and between acquiring it in real life. The exact question which the image answers in the former case is not what this phenomenon is but what this phenomenon, perceived by us, represents or pictures. We may therefore denote it as picturing meaning-image. In contrast

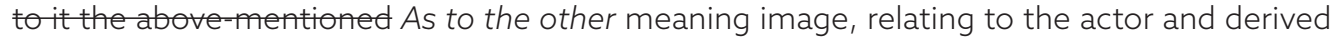
from our knowledge of the theatre and the artistic practice associated with it, we may call technical meaning-image. Roughly speaking we see that technical image remains an abstract image, while the picturing image, while fusing because it is merging with the sensorial perception, acquires a concrete perceptual character.

Thus a characteristic feature of the dramatic work is the fact that when attending perceiving [sensing, observing, watching] a theatrical performance we have two different meaning images simultaneously at once: the technical and the picturing. This is [a] exclusive specific property of art in general, but though not really of all its branches. I find myself in a picture gallery and stop before a painting work by Slaviček. What is it? A painting, more specified an oil painting. What does it represent? A landscape, more specified a landscape near Kameníčky. Painting evokes therefore both a technical image and a picturing image. I go to the Hradčany Prague Castle. What is it? A building, specified a Gothic church, St. Vitus's Cathedral. What does it represent? Nothing whatever; this question is altogether out of place. Architecture evokes therefore only a technical image. Forms of art that induce besides the technical images also the picturing images, and which do this essentially and not only casually, may be called picturing arts.

From the above we have to conclude that dramatic art is a picturing art and the same specification must be applied to is valid about (applies) the art of acting.

As we can see in the transcript, Osolsobě has maintained most of Kostomlatský's solutions, although he does not refrain from stylistic edits. These are rather minor, however, and are included to mirror Zich's original in a more direct way. Several crucial edits of Kostomlatskýs suggested translations of Zich's key term významová představa can be found in this excerpt. These changes, on the one hand, reflect Osolsobě's understanding of Zich's theory. ${ }^{1}$ On the other hand, they are in tune with the tendency of the time to include precise, semiotically specific terminology into academic texts in the field. Thus, the adjective 'semantic' ('významovy'), for example, having to do with meaning ('význam'), is substituted for 'significatory' [sic], in order to involve the same root as signification (also, 'význam'), yet in a semiotics-specific context. This gives the translation

1 For a comprehensive overview of Osolsobě's take on Zich, see (OSOLSOBĚ 2003; Osolsobě and Procházka's 'Notes and Commentaries' in OSOLSOBĚ and PROCHÁZKA 1986; and Osolsobě's postscript 'Zich's Philosophy of Dramatic Form' in OSOLSOBĚ 1986). 
a more precise terminology with clearly delineated contours, yet it moves away from Zich's pre-semiotic terminology, which is derived from traditions of German idealism, Herbartism (i.e. literal translations of German concepts into Czech, along with Hostinskýs aesthetic theories of the turn of the $20^{\text {th }}$ century). We may say that given the time of its creation, the translation would make a terminologically corresponding addition to the classics of the time in the English language, such as (ELAM 1980). The translation also reflects semiotic circles in which Osolsobě himself was an important figure. At the same time, since the 1980s many of the semiotics-specific choices made by Osolsober have become loaded with additional meanings, and thus may produce an air of outdatedness for the contemporary reader.

This brings us to an issue which cannot be escaped when producing a translation of a historical theoretical text. Should the translator attempt to render the target text in the language of the original era? Or should the translator attempt to ignore developments of language and especially field-specific terminology which have added meanings to the words which could have not been foreseen in any way by the original author? Should the target text, on the contrary, use corresponding terminology of the time the source text was produced, especially in this case, when an English version did not exist at the creation of the original?

These questions begin to delineate the scope of decisions that each translator must consider when approaching historical material. Save for the first strategy above, which would likely produce a strange fossil, 'stylized' translation, the range of choices outlined by the second and third are always involved. Would a literal translation of a word like vyzznam (meaning) be too general or should it be substituted with a more specific option like 'signification', which specifies the kind of meaning, including its sensual and operational dimension? In other words, how far can a translator proceed in their interpretation of the intended meanings of the source? This is a fundamental issue, with opinions varying among individuals as well as with trends in translation.

Below, the selected excerpt from The Aesthetics has been divided into paragraphs. Each paragraph from the original (ZICH 1986) is then accompanied by two translations. The one on the left is Kostomlatský's and includes Osolsobě's edits. The mirror translation on the right capitalizes on this translation, but has been heavily edited even to the level of a re-translation at the level of concepts, sentences, or even whole paragraphs, by Pavel Drábek and Tomáš Kačer, and further edited by David Drozd and Mark McEllan.

Kostomlatský and Osolsobě's translation includes many choices that imitate Zich's stylistic idiosyncrasies (staying close to the original) as well as introduces concepts from 1980s semiotics (moving away from it). The current translation changes the style into a more contemporary use of English (moving away from the original), while including more literal choices for concept translations despite new meanings acquired over time (staying close to it) and introducing solutions that capture the original intended meaning that add a minimum of surplus connotations that would entail an added theoretical framework (where a literal translation would use a word that is too heavily impregnated, thus hopefully, moving away only slightly from it). Using 'persona' (instead of 
person or character) may serve as an example of the former. The choice of 'ostensive' (where Kostomlatský and Osolsobě use 'perceptual) illustrate the latter approach to conceptual choices.

Changes of style have to do with readability and accessibility for the contemporary reader of English. Over the nearly ninety years since the first edition, Zich's style has grown archaic in Czech and many of his constructions and word-choices have become obscure: they were precise choices in his theoretical and linguistic background, but these traditions (German idealism, Herbartism and Hostinský) are generally not even understood by Czech readers today. For this reason, concepts of the mind, for example, have been substituted for by equivalents following the English empiricist tradition, rather than German idealism (in choices such as 'mental' instead of a more literal 'spiritual', for example).

Such an approach to the translation process has resulted in crucial editorial changes to the Kostomlatský and Osolsobě manuscript, which in practice meant returning to Zich's source text and re-translating much of it. Yet, many solutions introduced by the older translation have proven ingenious and in line with the current project. For example, Kostomlatský and Osolsobě systematically operate along the empiricist noetic chain, which involves concepts of a phenomenon and its perception, percept, the image (and the idea), a strategy which has been adopted.

At the top of each box below the source Czech paragraphs can be found, under which the two translation variants are aligned, with the manuscript of Kostomlatský and Osolsobě in the left column, and the our most recent translation on the right:

Po tomto rozboru „dramatického děje“ obrátíme se k analýze „dramatické osoby“. Bude poněkud obtížnější, protože je v podstatě noetická a vyžaduje pozorného a přesného rozlišování pojmů. (ZICH 1986: 42)

After the foregoing analysis of the 'dramatic

After the analysis of dramatic action, an analysis event' we shall turn to the analysis of the 'dramatic person'. It will be somewhat more difficult because it is essentially noetic and requires a careful and precise differentiation of the dramatic persona needs to follow. This is more challenging in that it is in fact noetic and requires a careful and precise differentiation of concepts.

of concepts.

Již na počátku rozboru jsme zjistili, že „dramatická osoba“ je vlastně naše představa, již si přimyslíme k relativně stálé složce dramatického vjemu. Podotkli jsme také již tam, že podobně je i ve skutečném životě. Každý náš poměrně stálý vjem vybavuje v naší zkušenosti na základě podobnosti nějakou představu, odpovídající na nejvšeobecnější otázku, co to je, co vidíme, slyšíme atd., pročež ji nazveme představou významovou. Tato představa nepochází tedy zvnějška, nýbrž od nás, z naší zkušenosti, a je podle této zkušenosti tu jen obecná, neurčitá a chudá, 
tu zvláštní, určitá a bohatá. Tak např. v nedávno uvedeném příkladu životního děje dramatického, totiž srocení lidu, jsou obecnější významové představy, nepředpokládající naše zvláštní zkušenosti: Jsou to lidé, mladí - staří, muži - ženy; speciálnější již: dělníci, strážníci; dokonce zvláštní pak třeba: poslanec X. Důležitá okolnost je ta, že tato významová představa, podložena jsouc vjemu, jímž byla na základě podobnosti vyvolána, splývá s nimi tak, že dostává charakter názornosti. (ZICH 1986: 42)

In the beginning of the present chapter we have stated that the 'dramatic person' is in fact our image, which we hypostatize to the relatively invariant component of the dramatic perception. And we have pointed out that we encounter a similar situation in real life. Each of our comparatively constant perceptions evokes in our experience on the basis of similarity some image that answers the very general question what does it mean that we see, hear, etc., and for this reason we shall call it a significatory or meaning image. Obviously, this image does not come to us from outside but from ourselves, from our own experiences, and is according to this experience sometimes only general, vague and poor, and sometimes particular, definite, and rich. Thus if we take the before-mentioned example of the dramatic event in real life, i.e. a street riot, we have as its observers partly rather general meaning images, not assuming any special experience on our part: These are people, either young or old, men or women; more particular images are e.g. workers, policemen, and fully particular image may be for ex ample congressman N.N. A important circumstance is here the fact that this meaning image, underlying the perception that evoked it on the basis of similarity, merges with the perception to such an extent that it acquires a perceptual character.
The beginning of this analysis has shown that the dramatic persona is in fact a mental image that we add in our mind to a relatively constant element of dramatic perception. (Just to iterate: early on, we pointed out that this is similar to real life. Each of our relatively constant perceptions evokes in our experience some image on the basis of similarity.) This image is a response to the most general question: what is it that we can see or hear? For this reason we shall call it the conceptual image (or the image, for short). This image does not come to us from the outside but from within, from our experience, and so may be - depending on the quality of our experiences - general, vague and pallid, or else specific, definite and intense. Our above example of a real-life dramatic action (the public demonstration) involves more general images, which do not assume any extraordinary experience on our part; there are people, young and old, men and women; and even more particularly, there are workers and policemen; and even more specifically, there might be a particular Member of Parliament, Mr. X. What is important here is this: the conceptual image, underpinning the perception that evoked it on the basis of similarity, merges with the perception itself; and they blend to such a degree that the conceptual image acquires an ostensive quality. 
Tak je tomu is významovou představou při vnímání dramatického děje umělého, tedy divadelního. I ta je podle naší zkušenosti obecnější nebo zvláštnější (např. mladý muž - princ - Hamlet) a i ta má ráz názornosti. Ale při divadelním představení, jak jsme ostatně také již naznačili, nepřestáváme na této jediné významové představě. Přesná odpověd’ na otázku „co to je?“ zní totiž ted’: ve skutečnosti je to, co vnímám, herec. Tato druhá významová představa nevybaví se mi však na základě podobnosti s vjemem; tu mi poskytne moje zkušenost divadelní, a to abstraktně, ba proti názoru; já to vím, že je to nějaký herec, popřípadě (podle divadelní cedule) určitý herec $\mathrm{A}$, ač vidím a slyším někoho jiného, třeba prince Hamleta. Nesplývá tedy tato druhá významová představa s názorem, její ráz zůstává abstraktní, a to i tehdy, když mi leckteré drobné detaily (rysy obličeje, témbr hlasu) prozrazují a dotvrzují, že to je doopravdy přece jen herec A. Vidíme tedy, že je to s významovou představou dramatické osoby, divadelní (proti životní) jinak. Přesná otázka, na niž představa ta odpovídá, nezní totiž „co to (tento zjev) je“, nýbrž, „co tento zjev, námi vnímaný, predstavuje nebo zobrazuje?“ Nazveme ji tudíž významovou představou obrazovou. Naproti tomu řečenou významovou představu herce, pocházející z našich znalostí divadla a jeho umělecké praxe, nazveme významovou představou technickou. Zhruba vzato, zůstává technická představa naše abstraktní, kdežto obrazová, splývajíc s vjemem, přijímá ráz názorný. (ZICH 1986: 42-43)

The same holds good also in the case of the meaning image that is associated with our perception of an artificial dramatic event that is of the theatre. Here, too, the image is in our experience either more general or more particular (e.g. young man - a prince - Hamlet) and it also acquires a perceptual character. Yet, in the course of a theatrical performance, as we have already pointed out, we are not content with one meaning image. The precise answer to the question what it is that we perceive is namely the following: What I perceive is, in fact, an actor. This second meaning image, however, does not originate in me on the basis of similarity with the sensorial perceptions; it is mediated to me by my experience of the theatre, and, as a matter of fact, in an abstract way contrasting with the perception: I simply know he who is some actor, maybe even a certain actor (as the play-bill tells me) although I see and hear somebody else, let us say Prince Hamlet. Thus this second meaning image does not merge with the concrete perception, its character remains
The same holds true for the image during our perception of artificial dramatic action - the theatre. These images may range from general to particular, based on the quality of our experiences (for example, a young man - a prince - Hamlet), and they also have an ostensive quality. But in the case of a theatre performance, as we have already pointed out, we do not limit ourselves to a single image. An accurate answer to the question "What is it?" is: what I perceive now is, in fact, an actor. This latter image does not emerge on the basis of similarity with the perception. It is given by my theatrical experience, and that in an abstract way, and in clear contrast to the perception: I know this is an actor, and even a particular one (credited in the programme); but I see and hear someone else, say Prince Hamlet. This image therefore does not merge with the perception but remains abstract; and that is so even at times when several minor details (such as facial features and timbre) suggest otherwise and betray that particular actor. So, clearly, the image of a dramatic persona in the 
abstract even in those moments when a few minor details (features of the face, timbre of the voice) betray and confirm the fact that it actually is the actor in question. Thus we realize that there is a difference between acquiring a meaning image of a dramatic person on the stage and between acquiring it in real life. The exact question which the image answers in the former case is not what this phenomenon is but what this phenomenon, perceived by us, represents or pictures. We may therefore denote it as picturing meaning-image. As to the other meaning image, relating to the actor and derived from our knowledge of the theatre and the artistic practice associated with it, we may call technical meaning-image. Roughly speaking we see that technical image remains an abstract image, while the picturing image, because it is merging with the sensorial perception, acquires a perceptual character. theatre is different from real life. As a matter of fact, the image of a dramatic persona is not a response to the question "What is it (this phenomenon)?", but rather "What does this phenomenon, perceived by us, represent or imitate?". Let us call it the symbolic image. Opposed to that, let us call the image of the actor - which is based on our knowledge of the theatre and its practice - the technical image. In broad terms, the technical image remains abstract, while the symbolic image - which merges with the perceptions - takes on an ostensive quality.

Je tedy pro dramatické dílo příznačné, že máme při jeho vnímáni dvě odlišné významové prédstavy najednou; technickou a obrazovou. To je výlučná vlastnost umění vůbec, nikoli však všech jeho oborů. Procházím galérií a zastavím se před „Slavíčkem“. Co je to? Obraz, spec. olejový obraz. Co to představuje? Krajinu, spec. krajinu od Kameniček. Malířství tedy má představu technickou i obrazovou. Zajdu si na Hradčany. Co je to? Budova, spec. gotický chrám, dóm Svatovítský. Co představuje? Nic, pranic; tato otázka nemá význam. Stavitelství tedy má pouze představu technickou. Umění, vyvolávající vedle představ technických též obrazové, a to podstatně, nejen př́ípadně, nazveme umění obrazová. (ZICH 1986: 43)

Thus a characteristic feature of the dramatic work is the fact that when perceiving a theatrical performance we have two different meaning images at once: the technical and the picturing. This is a specific property of art in general, though not really of all its branches. I find myself in a picture gallery and stop before a work by Slavíček. What is it? A painting, more specified an oil painting. What does it represent? A landscape, more specified a landscape near Kameníčky. Painting evokes therefore both
It follows that our experience of a dramatic work consists of two different images at once: the technical and the symbolic. This is an exclusive characteristic of art in general, yet not of all of its disciplines. I walk through a gallery and stop in front of a Turner. What is it? A painting, more specifically, an oil painting. What does it represent? A landscape, more specifically, a landscape in Italy. Thus, visual arts include both the technical image and the symbolic image. I have a walk to Prague Castle. 
a technical image and a picturing image. I go to the Prague Castle. What is it? A building, specified a Gothic church, St. Vitus's Cathedral. What does it represent? Nothing whatever; this question is altogether out of place. Architecture evokes therefore only a technical image. Forms of art that induce besides the technical images also the picturing images, and which do this essentially and not only casually, may be called picturing arts.
What is it? A building, more specifically, a Gothic church, St. Vitus Cathedral. What does it represent? Nothing whatsoever; the question makes no sense. Thus, architecture only includes the technical image. Those art disciplines which include both the symbolic image as well as the technical image - and that essentially, not just accidentally - will be called mimetic arts (or representing arts).

Z vylíčeného plyne, že dramatické uměni je uměni obrazové a že totéž platí i o herectvi samém. (ZICH 1986: 43)

From the above we have to conclude that dramatic art is a picturing art and the same is valid about the art of acting.
It follows from the above that dramatic art is mimetic and the same holds for acting itself.

This passage includes some of the most crucial choices that had to be made by the current translation team. The translation of the central concept of Zich's Aesthetics, významová představa, has maintained Kostomlatský and Osolsobě's choice of 'image' (i.e. the object of one's imagination), but has substituted 'conceptual' for 'significatory' [sic] or 'meaning'. The choice has been made on the presumption that the image is that of the idea itself rather than the meaning that it produces (which would be rendered as 'idea'). However, two aspects of idea prove even more problematic. While the material aspect, i.e. the 'technical' image, has the generally understandable relation to a technique of an artist's work with the material (it is a technicality, after all), the content that is evoked is the 'symbolic' image. The latter may seem as a problematic choice, especially as the source uses obrazová, an expression closely related to a (visual) representation. But there is no one object in the world out there that is represented (an objectively existing Hamlet, to use Zich's example). It is merely content in the mind's eye of the viewer that is created. This aspect of the idea is then, in the current translation's rendering, rather a symbol than a representation (or, a 'picture' in the narrow, visually determined sense). Despite this choice seeming better than 'pictorial' or 'picturing' [sic], the term 'symbolic' is problematic, as the concept of a symbolic relation can be seen to involve no other connection between the object and its symbol than arbitrariness. Still, this choice has been made in full awareness of the fact that Zich's epistemological groundwork is laid on a different tradition than that of the arbitrariness of the symbolic relation in the theory of denotation since Saussure. Yet, the danger of introducing arbitrariness into Zich's theory may lead to a substitution, eventually. As the current translation is still a work in progress, the team are still considering 'representational image' as a solution 
to longstanding conundrum of rendering významová predstava obrazová in translation.

After all, several articles in the present issue of Theatralia demonstrate that there is no perfect translation of the concept. The editors of the issue have decided to stick to each individual author's use of the translation/s that they are used to and which best serves their purpose. It also follows from the above condensed summary of a long discussion of the translation of the concept that there is no 'perfect' translation. To many who are familiar with Zich's work in the original, it seems clear that Zich's word choice was more a provocation toward a new way of thinking about the cognitive processes of the viewer while watching a performance than a definitively rigid description.

Along with 'symbolic', there is one more term used in the current translation that has a similar potential to cause a heated argument among theatre theorists. The word is 'mimetic'. It is important to note that this translation is used for the same Czech expression (both stand for obrazový) used in different contexts. This word choice partly expresses a conservative attitude to translating a concept related to representation, and is in part based on a belief that sometimes the reader should take the context of the original as a historical given. As for the conservatism, this is in line with Zich's own attitude to drama and theatre (clearly deducible from various other parts of The Aesthetics). In short, Zich understood the notion of representation in the Aristotelian sense as mimesis: as performing action from the world of our lived experience on stage. He can be seen as relatively conservative in his view of the theatre (the material of his enquiry) when we consider that The Aesthetics was published in 1931. Despite contemporary trends, Zich deliberately ignored all avant-garde theatre concepts, sticking more to early modernist notions of theatre art which might be represented by Gordon Craig, Adolphe Appia, Max Reinhardt or Konstantin Stanislavski. We should seriously consider the fact that already by 1915 Zich had presented his first lecture on the topic of his future Aesthetics. The main arguments and concepts behind the book had been developed for many years before it was finally finished, thus by that time the central premises of the work had become retrograde.

The decision to use 'mimetic' is also based on a consideration of the context of the original. It was agreed among the translators' team to simply ignore the discussion of mimesis as witnessed in the last fifty or so years. In other words, the translation remains as retrograde today as Zich himself was in his own time. The history of mimesis as concept is generally well known and we believe that the reader may comfortably orient themselves to grasp the notion of mimesis at the beginning of the $20^{\text {th }}$ century as viewed by Zich and his contemporaries.

By way of concluding this discussion of the archival material just presented, let us quote Samuel Kostomlatskýs postscript to his translation draft of The Aesthetics. The addendum illustrates the struggles the translator faced and his awareness of a principal issue that complicates the task: Otakar Zich's writing is grounded in a tradition of reasoning that is in a direct opposition to principles of 'English essayistic literature,' as Kostomlatský calls it. Simply put, Zich operates on the abstract level and his examples serve as accidental illustrations of his general points; his terminology is heavily dependent on the German idealist and aesthetics traditions and in the experimental psychology of his time. 
Let us give an example - his use of the adjective názorný, which is a mirror translation of the German anschaulich, and carries with it all the baggage of the $18^{\text {th }}$ and $19^{\text {th }}$ century discussions of the nature of representation. Depending on the context, this abstract expression may be translated in many ways, each emphasizing a particular ('concrete') aspect of the expression, yet never encompassing all the implied meanings of názorný/anschaulich. The English language offers the following (all of which have been considered in the translation of The Aesthetics and would find its proper place in a particular context): directly demonstrative, manifestly demonstrative, graphic, observable, manifest, explicit, intelligible, sensible, tangible. The list could go on.

Czech and German even have a single word for the quality of being názorný/anschaulich - it is názornost/unschaulichkeit. The current translating team has agreed on using 'the ostensible quality' in most contexts that this expression appears. Like so many other solutions, this choice remains imperfect and should be taken as yet another example of the many possibilities entailed in this work in progress. This word choice resonates with certain statements that Samuel Kostomlatský felt he needed to add to his translation draft:

\section{The Translator's Marginal Note}

By way of introducing the English version of the present work the translator takes the liberty of putting a native English reader a somewhat unconventional question: What would you do if you were to translate into English a significant work of a foreign scientist, indulging profusely in abstract diction - both general and individual of his own coinage - while the good tradition of English essayistic literature bids you to avoid excessive abstract formulation? Now - the message of the work is one of a vital and original appeal to initiated reader of any nation, and it wants to be heard. What else is to be done but to make the English language, so intimately acquainted with practical life and concrete imagination, convey the message? Finally you will simply have to perform the task, striving hard all the time to emerge from this maze with an English that is still English and with the scientific author who is still communicating to the reader his ideas in his individual way of conceiving them. Otherwise they would no more be his ideas - and, after all, you are supposed to translate the work and not to re-write it.

\section{Bibliography}

ELAM, Keir. 1980. Semiotics of Theatre and Drama. London: Methuen, 1980.

OSOLSOBĚ, Ivo. 1986. Zichova filozofie dramatického tvaru [Zich's Philosophy of the Dramatic Form]. In Otakar ZICH. Estetika dramatického uměni. Teoretická dramaturgie [The Aesthetics of Dramatic Art. A Theoretical Dramaturgy]. Prague: Panorama, 1986: 373-399.

OSOLSOBĚ, Ivo and Miroslav PROCHÁZKA. 1986. Poznámky a komentáře [Notes and Commentaries]. In Otakar ZICH. Estetika dramatického uměni. Teoretická dramaturgie [The Aesthetics of Dramatic Art. A Theoretical Dramaturgy]. Prague: Panorama, 1986: 329-372. 
OSOLSOBĚ, Ivo. 2003a [1970]. Dramatické dílo jako komunikace komunikací o komunikaci [Dramatic Art as Communication through Communication about Communication]. Ostenze, hra, jazyk [Ostension, Play, Language]. Brno: Host, 2003: 90-137.

OSOLSOBĚ, Ivo. 2003b [1981]. Sémiotika sémiotika Otakara Zicha [Semiotics of the Semiotician Otakar Zich]. In id. Ostenze, hra, jazyk [Ostension, Play, Language]. Brno: Host, 2003: 213-238.

OSOLSOBĚ, Ivo. 2007a [1975]. Sémiotika v Tampě a okolí, poslouchaná divadelníkem [Semiotics at Tampa and Around, as Witnessed by Theater-maker]. In id. Principia parodica. Prague: NAMU, 2007: 235-246.

OSOLSOBĚ, Ivo. 2007b. Dg.: Semiotica Theatralic Chronica. In id. Principia parodica. Prague: NAMU, 2007: 259-264.

SEBEOK, Thomas A. and Marcel DANESI (eds.). 1986. Encyclopedic Dictionary of Semiotics. Berlin/Boston: De Gruyter, 1986.

ZICH, Otakar. 1986. Estetika dramatického umění. Teoretická dramaturgie [The Aesthetics of Dramatic Art. A Theoretical Dramaturgy]. Prague: Panorama, 1986. 